\title{
PERKEMBANGAN DAN DINAMIKA SUBJEK SENGKETA
}

\section{ANTROPOLOGI HUKUM}

\author{
Farhansyah Amrizal \\ farhansyahamrizal@gmail.com \\ 2110003600253 \\ Universitas Ekasakti
}

\section{A. PENDAHULUAN}

Indonesia merupakan negara yang berbentuk kepulauan dengan aneka ragam suku bangsa dan budaya, juga memiliki keanekaragaman hukum adat. Keanekaragaman hukum tersebut pada akhirnya melahirkan perbedaan dari masing-masing daerah dalam hal penyelesaian konflik. Masing-masing daerah mempunyai mekanisme penyelesaian konflik sendiri-sendiri. Juga perlu dipahami bahwa Indonesia dengan mayoritas penduduk muslim terbesar.

Perkembangan yang terjadi dalam kehidupan manusia selalu berhadapan dengan konflik yang mewarnai kehidupan, berawal dari permasalahan yang mengiringi setiap aktivitas dalam kehidupan manusia. Bervariasinya permasalahan yang menimbulkan konflik tentunya tidak selalu dapat diselesaikan dalam waktu yang sesingkat-singkatnya dengan hasil dari pemecahan masalah yang dapat diterima bagi para pihak yang berselisih bahkan tidak jarang berujung pada munculnya sengketa.

Namun sebagai makhluk ciptaan Tuhan yang sempurna, manusia tentunya senantiasa mengusahakan dan berupaya dengan berbagai cara terbaik untuk tercapainya solusi yang diinginkan, sehingga terciptanya keseimbangan dan keselarasan dalam kehidupan manusia. Oleh Karena itu 
diharapkan bukan hanya adanya pihak yang menang atau kalah namun lebih diupayakan dapat melahirkan kesepakatan antara pihak-pihak yang bersengketa dengan mufakat dirasakan dapat memenuhi keinginan para pihak tersebut (win-win solution).

Konsep "unifikasi hukum" telah diterapkan cukup lama di Indonesia, upaya ini untuk menjaga hak-hak individu. Bisa dilihat pada berbagai peraturan perundang-undangan yang telah diubah suai dengan konsepsi diatas. Contoh yang bisa dipahami khususnya pada kajian hukum keluarga yakni pada UU Nomor 1 Tahun 1974 tetang perkawinan, seperti diketahui UU ini ditujukan untuk menggantikan enam sistem hukum lain yang tadinya berlaku untuk pelbagai golongan masyarakat di tanah air. Tujuan unifikasi peraturan perundangan tersebut adalah agar terjadi pelaksanaan hukum yang terkoordinasi, lebih tertib dan kinerjanya diharapkan meningkat.

Kemajemukan masyarakat Indonesia, perbedaan yang ada, konflik yang mungkin dapat timbul, tidak selamanya dapat diselesaikan dengan menggunakan hukum yang telah ditetapkan oleh pemerintah pusat yang menggunakan prinsip keseragaman :menganggap bahwa masyarakat yang satu sama dengan masyarakat yang lain.

Hasil dari penerapan sentralisasi selama ini adalah ketidakpuasan baik dari masyarakat, maupun pihak-pihak yang bertikai (dalam hal ini pelaku dan korban). Adalah kenyataan sesungguhnya bahwa hukum nasional belum tentu dapat menjamin keadilan yang diinginkan semua pihak, dan belum tentu bisa memulihkan kondisi masyarakat yang rusak 
akibat konflik tersebut. Hukum nasional hanya berpedoman bagaimana melindungi masyarakat, tanpa melihat apakah kepentingan masyarakat dan pihak-pihak yang bertikai telah dilindungi. Bagi masyarakat ditiap-tiap daerah yang masih berpegang pada aturan-aturan adat penyelesaian konflik dengan menggunakan hukum adat dirasakan lebih menjamin keadilan dan lebih memiliki kekuatan nilai dibandingkan hukum nasional yang cenderung kurang berpihak. Hal ini disebabkan karena hukum adat merupakan kesepakatan bersama dari masyarakat setempat yang telah mempertimbangkan kepentingan-kepentingan masyarakat, individu, maupun pihak yang bertikai.

Benturan antara state laws (hukum nasional) dengan the other laws (hukum adat lokal)3 menjadi diskursur tersendiri bagi kalangan akademisi untuk mempelajari lebih lanjut. Apalagi jika sudah terjadi sengketa, tentu akan timbul tensi yang bisa jadi tinggi maupun rendah dalam penyelesaian masalah. Dengan adanya kemajemukan masyarakat, tentu hal ini tidak dipisahkan. Pluralisme ini membawa suatu konsep yang berbeda khususnya dalam tatanan hukum di Indonesia, sehingga dalam penetapan hukum nasional, tentu tidak boleh juga lepas dari hukum dari masyarakat. Tujuannya adalah unifikasi didalam masyarakat.

Konsep antropologi dalam pandangan hukum sebenarnya telah lama dibicarakan oleh para pakar, khususnya pada zaman kolonialisme, hal ini tentunya dengan tujuan tertentu yang mereka buat. Namun metode selalu menarik untuk ditelusuri kembali terutama dalam kajiankajian studi islam yang berkembang di masyarakat Indonesia. Tulisan ini berupaya 
untuk mendalami perkembangan dan dinamika subjek sengketa dalam kajian antropologi hukum.

\section{B. PEMBAHASAN}

\section{a. Sengketa}

Sengketa dalam kamus bahasa Indonesia dimaknai dengan bentrokan, cedera, friksi, kelahi, konflik, konfrontasi, perbalahan, pergesekan, perselisihan, pertengkaran, pertentangan, pertikaian. Jadi dapat disimpulkan bahwa sengketa merupakan suatu masalah sosial yang bersifat universal. Karena itu, konflik tidak perlu dilihat sebagai gejala patologis yang bersumber dari tingkah laku abnormal, atau indikasi dari suatu kekacauan dalam dinamika kehidupan masyarakat, karena setiap komunitas masyarakat mempunyai kapasitas untuk menciptakan normanorma dan mekanisme-mekanisme tersendiri untuk menyelesaikan sengketa yang muncul dalam pergaulan sosial warga masyarakat.

Di lihat dari kajian antropologi hukum, fenomena sengketa mempunyai dua makna, yaitu pertama sengketa mempunyai makna menimbulkan perpecahan atau disintegrasi suatu kehidupan sosial, melemahkan kohesi sosial, atau menimbulkan kerusakan suatu sistem hubungan sosial dalam masyarakat. Kedua, sengketa juga memiliki makna positif dalam mempertahankan integrasi sosial, memperkokoh ikatan sosial, dan memberi kontribusi untuk mengembalikan keseimbangan hubungan sosial antar individu atau kelompok dalam masyarakat. Yang disebutkan terakhir akan dapat terwujud apabila pihak-pihak yang bersengketa secara bersama-sama dapat mengelola, mengendalikan, dan 
menyelesaikan sengketa yang dihadapi secara dewasa, bijak, dan damai, dengan atau tanpa mengundang kehadiran pihak ketiga.

Dengan kata lain, berdasarkan kajian antropologi hukum dikatakan sengketa tidak selalu bermakna negatif dalam kehidupan masyarakat, karena sengketa juga mempunyai makna positif yang dapat memperkokoh integrasi dan kohesi hubungan sosial dalam masyarakat, atau mengembalikan keseimbangan hubungan dan sendi-sendi kehidupan sosial.

Jadi, sesungguhnya sengketa yang terjadi dalam masyarakat mengandung arti yang konstruktif dan bersifat integratif, karena sengketa juga mempunyai kekuatan tersendiri untuk membentuk, mengembangkan, menertibkan ulang suatu relasi sosial, interaksi, atau tatanan kehidupan yang sudah ada dalam masyarakat.

\section{b. Penyebab Terjadinya Sengketa}

Secara umum dikatakan bahwa terjadinya sengketa dalam masyarakat bersumber dari persoalan-persoalan seperti berikut:

a. Penguasaan, pemanfaatan dan distribusi sumber daya alam yang menjadi pendukung kehidupan manusia (natural resource control and distribution)

b. Ekspansi batas wilayah kehidupan suatu kelompok

c. Kegiatan ekonomi masyarakat (economic activities)

d. Kepadatan penduduk

e. Hukum dan kebijakan pemerintah

f. Politik 
g. Kemiskinan dari perspektif antropologi hukum, sengketa yang terjadi dalam masyarakat paling tidak dapat dikategorisasi menjadi 3 (tiga) macam, yaitu (a) Konflik kepentingan (conflict of interests); (b) Konflik nilainilai (conflict of values); dan (c) Konflik normanorma (conflict of norms).

Dalam hubungan ini, Nader dan Todd (1978) menyatakan bahwa pada dasarnya sengketa yang terjadi dalam masyarakat melalui tahapantahapan (stages of conflict) seperti berikut:

a. Pada tahap pertama, sengketa berawal dari munculnya keluhankeluhan (grievance) dari salah satu pihak terhadap pihak yang lain (individu atau kelompok), karena pihak yang mengeluh merasa hak-haknya dilanggar, diperlakukan secara tidak wajar, kasar, dipersilahkan, diinjak harga dirinya, dirusak nama baiknya, dilukai hatinya, dll. Kondisi awal seperti ini disebut sebagai tahapan prakonflik (pro-conflict stage) yang cenderung mengarah kepada konfrontasi yang bersifat monadik (monadic).

b. Pada tahap kedua, apabila kemudian pihak yang lain menunjukkan reaksi negatif berupa sikap yang bermusuhan atas munculnya keluhankeluhan dari pihak yang pertama, maka kondisi ini meningkat eskalasinya menjadi situasi konflik (conflict stage), sehingga konfrontasi antar pihak-pihak berlangsung secara diadik (diadic). 
c. Pada tahap ketiga, apabila kemudian konflik antar pihak-pihak tersebut ditunjukkan dan bawa ke arena publik (masyarakat), dan kemudian diproses menjadi kasus perselisihan dalam institusi penyelesaian sengketa tertentu dengan melibatkan pihak ketiga, maka situasinya telah meningkat menjadi sengketa (dispute stage), dan sifat konfrontasi antar pihakpihak yang berselisih menjadi triadik (triadic).

\section{c. Penyelesaian Sengketa dalam Kajian Antropologi Hukum}

Penyelesaian dalam sengketa Antropolgi Hukum. Setiap bentuk masyarakat di mana pun dan kapan pun pada dasarnya mempunyai kemampuan untuk menciptakan norma-norma dan mekanismemekanisme, serta membangun institusi-institusi tertentu untuk menyelesaikan setiap sengketa yang muncul dalam masyarakat.

Masyarakat memberi makna sengketa sebagai bagian dari dinamika kehidupan sosial, dan makna sengketa yang diberikan masyarakat juga sangat tergantung pada nilai-nilai, kepercayaan, dan norma-norma yang dianut, serta bentuk-bentuk institusi sosial yang dibangun untuk menyelesaikan sengketa (Roberts, 1978).

Sistem nilai, norma, politik, ekonomi, dan keyakinan sangat mempengaruhi pilihan bentuk institusi dan model-model penyelesaian sengketa dalam masyarakat. Institusi penyelesaian sengketa yang dikenal dalam masyarakat paling tidak ada 2 (dua) macam, yaitu: 
a. Institusi penyelesaian sengketa yang bersifat tradisional, yang bersumber dari sistem politik dan hukum rakyat dan berlangsung secara tradisional (folk institutions).

b. Institusi penyelesaian sengketa yang dibangun dan sistem politik dan hukum negara (state institutions).

Dalam kondisi masyarakat yang masih sederhana dan subsisten, di mana relasi antar individu, hubungan kekerabatan dan kelompok masih kuat, maka pilihan institusi untuk menyelesaikan sengketa diarahkan kepada institusi-institusi penyelesaian sengketa yang bersifat kerakyatan (folk institutions), karena institusi penyelesaian sengketa yang bersifat tradisional bermakna sebagai institusi penjaga keteraturan sosial (social order) dan dimaksudkan untuk pengembalian keseimbangan magis dalam masyarakat.

Karena itu, makna penyelesaian sengketa melalui institusi tradisional dengan mengacu pada hukum rakyat (folk law) lebih ditujukan untuk mengembalikan hubungan sosial yang terganggu dan lebih dari itu mengembalikan keseimbangan magis dalam masyarakat (win-win solution).

Sedangkan, sengketa yang terjadi dalam masyarakat yang kompleks dan modern, di mana relasi sosial lebih bersifat individualistik, berorientasi pada perekonomian pasar, cenderung diselesaikan melalui institusi penyelesaian sengketa yang formal dengan mengacu pada hukum negara (state institution) yang bercirikan legalistik. 
Institusi peyelesaian sengketa yang mengacu pada hukum negara dikenal sebagai pengadilan (court institution), yang digerakkan oleh hakim-hakim pengadilan (judges), dengan menerima, memeriksa dan memutuskan suatu sengketa untuk menyatakan pihak yang satu menang dan pihak yang lain kalah dalam sengketa tersebut (win-lose solution).

Sedangkan, model-model penyelesaian sengketa yang dikenal dalam masyarakat sederhana maupun kompleks (modern) pada pokoknya adalah:

a. Negosiasi, melalui proses kompromi antara pihak-pihak yang bersengketa, tanpa mengundang kehadiran pihak ketiga untuk menyelesaikan sengketa yang terjadi di antara mereka.

b. Mediasi, melalui kesepakatan antara pihak-pihak untuk melibatkan pihak ketiga (mediator) dalam penyelesaian sengketa, walau hanya berfungsi sebatas perantara (go-between) yang bersifat pasif, karena inisiatif untuk mengambil keputusan sebagai wujud penyelesaian sengketanya tetap didasarkan pada kesepakatan pihak-pihak yang bersengketa.

c. Arbitrasi, melalui kesepakatan untuk melibatkan pihak ketiga yang disebut arbitrator sebagai wasit yang memberi keputusan dan keputusan tersebut harus ditaati dan dilaksanakan oleh pihak-pihak yang bersengketa.

d. Ajudikasi, sebagai model penyelesaian sengketa melalui institusi pengadilan yang keputusannya mengikat pihak-pihak yang bersengketa (Roberts, 1978). 
Namun demikian, selain model-model penyelesaian sengketa seperti di atas, dalam masyarakat dikenal juga model-model penyelesaian sengketa seperti:

a. Tindakan kekerasan (coersion), sebagai aksi yang bersifat unilateral dengan mengandalkan kekuatan fisik dan kekerasan, seperti melakukan tindakan hukum sendiri (self-hell) atau dalam bentuk perang antar suku (warfare).

b. Tindakan membiarkan saja (lumping it), yang dilakukan oleh salah satu pihak dengan tidak menanggapi keluhan, gugatan, tuntutan pihak yang lain, atau mengabaikan sengketa yang teadi dengan pihak yang lain.

c. Tindakan penghindaran (avoidance), yang dilakukan salah satu pihak dengan menghindari sengketa dengan pihak lain, karena sejak awa! sengketa yang bersangkutan merasa secara sosial, ekonomi, politik, dan psikologis merasa sudah tidak berdaya untuk menghadapi pihak yang lain.

Dengan demikian, tindakan menghindari sengketa dipandang paling aman dan menguntungkan tidak saja bagi diri sendiri, tetapi juga bagi keluarga dan kerabat, dalam rangka menjaga hubungan sosial yang bersifat jangka panjang (Nader \& Todd, 1978).

\section{PENUTUP}

Model-model penyelesaian sengketa di atas sangat dipengaruhi oleh sistem nilai, keyakinan, norma, persepsi, dan sikap-sikap masyarakat dalam memaknai sengketa, dan dimensi-dimensi ini dalam perspektif 
antropologi hukum dikenal sebagai budaya hukum (legal culture) masyarakat dalam penyelesaian sengketa (Warasih, 1981).

Pertanyaan yang muncul kemudian, bagaimanakah budaya hukum penyelesaian sengketa yang dianut masyarakat Indonesia? Dalam hubungan ini, Lev (1972) pernah melakukan penelitian mengenai budaya hukum penyelesaian sengketa dalam masyarakat Indonesia, khususnya masyarakat di daerah pedesaan Jawa dan Bali. Temuan penelitian tersebut pada pokoknya menyatakan seperti berikut:

a. Dalam kehidupan sosial sebagian besar masyarakat Indonesia cenderung untuk menghindari terjadinya sengketa dengan siapa pun, karena nilai-nilai pergaulan sosial yang dianut lebih bersifat personal, komunal, mengutamakan solidaritas, dan bernuansa magis. Karena itu, apabila terjadi sengketa maka cenderung diselesaikan melalui prosedur kompromi, konsiliasi, mengutamakan pendekatan personal dan kekerabatan .

b. Sengketa antar individu sedapat mungkin dihindari, dan kalau pun harus terjadi maka sengketa cenderung ditutupi dengan gaya hubungan sosial yang halus, untuk memperoleh penyelesaian yang tidak sampai merusak hubungan dan pergaulan sosial, apalagi menjatuhkan martabat atau merendahkan derajat pihak yang diajak bersengketa.

c. Fokus penyelesaian sengketa bukan pada penerapan peraturan hukum yang digunakan, tetapi Iebih pada upaya pelenyapan sengketa yang menjadi sumber ketegangan sosial. 
d. Makna penyelesaian sengketa pada persoalan kalah-menang (winlose solution), tetapi menjadi kewajiban bagi pihak-pihak untuk menghentikan sengketa dan meniadakan ketegangan sosial yang telah terjadi. Karena itu, yang diutamakan bukan penyelesaian substansi sengketanya, tetapi Iebih pada prosedur penyelesaian sengketanya.

e. Pihak-pihak yang bersengketa Iebih melihat pihak ketiga (petugas hukum) yang dilibatkan untuk menyelesaikan sengketanya dan pada peraturanperaturan hukum yang mengatur penyelesaian sengketanya. Karena itu, petugas hukum ditaati masyarakat bukan karena alasan yang berkaitan dengan masalah kepatuhan masyarakat terhadap hukum. 


\section{Daftar Pustaka}

Darmini Roza dan Laurensius Arliman S, Peran Pemerintah Daerah Di Dalam Melindungi Hak Anak Di Indonesia, Masalah-Masalah Hukum, Volume 47, Nomor 1, 2018. https://doi.org/10.14710/mmh.47.1.2018.10-21

Laurensius Arliman S, Peranan Metodologi Penelitian Hukum di Dalam Perkembangan Ilmu Hukum di Indonesia, Soumatera Law Review, Volume 1, Nomor 1, 201. http://doi.org/10.22216/soumlaw.v1i1.3346.

Laurensius Arliman S, Peran Badan Permusyawaratan Desa di Dalam Pembangunan Desa dan Pengawasan Keuangan Desa, Padjadjaran Journal of Law, Volume 4, Nomor 3, 2017. https://doi.org/10.15408/jch.v4i2.3433.

Laurensius Arliman S, Penanaman Modal Asing Di Sumatera Barat Berdasarkan UndangUndang Nomor 25 Tahun 2007 Tentang Penanaman Modal, Supremasi Hukum, Volume 1, Nomor 1, 2018. http://dx.doi.org/10.36441/hukum.v1i01.102.

Laurensius Arliman S, Memperkuat Kearifan Lokal Untuk Menangkal Intoleransi Umat Beragama Di Indonesia, Ensiklopedia of Journal, Volume 1, Nomor 1, 2018, https://doi.org/10.33559/eoj.v1i1.18.

Laurensius Arliman S, Perkawinan Antar Negara Di Indonesia Berdasarkan Hukum Perdata Internasional, Kertha Patrika, Volume 39, Nomor 3, 2017, https://doi.org/10.24843/KP.2017.v39.i03.p03.

Laurensius Arliman S, Partisipasi Masyarakat Di Dalam Pengelolaan Uang Desa Pasca Undang-Undang Nomor 6 Tahun 2014 Tentang Desa, Jurnal Arena Hukum, Volume $12, \quad$ Nomor 2019 , https://doi.org/10.21776/ub.arenahukum.2019.01202.5.

Laurensius Arliman S, Mewujudkan Penegakan Hukum Yang Baik Di Negara Hukum Indonesia, Dialogica Jurnalica, Volume 11, Nomor 1, 2019, https://doi.org/10.28932/di.v11i1.1831.

Laurensius Arliman S, Mediasi Melalui Pendekatan Mufakat Sebagai Lembaga Alternatif Penyelesaian Sengketa Untuk Mendukung Pembangunan Ekonomi Nasional, UIR Law Review, Volume 2, Nomor 2, 2018 , https://doi.org/10.25299/uirlrev.2018.vol2(02).1587

Laurensius Arliman S, Peranan Filsafat Hukum Dalam Perlindungan Hak Anak Yang Berkelanjutan Sebagai Bagian Dari Hak Asasi Manusia, Doctrinal, Volume 1, Nomor 2,2016.

Laurensius Arliman S, Ni Putu Eka Dewi, Protection of Children and Women's Rights in Indonesia through International Regulation Ratification, Journal of Innovation, Creativity and Change Volume 15, Nomor 6, 2021. 
Laurensius Arliman S, Gagalnya Perlindungan Anak Sebagai Salah Satu Bagian Dari Hak Asasi Manusia Oleh Orang Tua Ditinjau Dari Mazhab Utilitarianisme, Jurnal Yuridis, Volume 3, Nomor 2, 2016, http://dx.doi.org/10.35586/.v3i2.180.

Laurensius Arliman S, Tantangan Pendidikan Kewarganegaraan Pada Revolusi 4.0, Jurnal Ensiklopedia Sosial Review, Volume 2, Nomor 3, 2020. 